\title{
不整量を有する構造物の強度について(その 1$)$
}

一一初期撓反を有する柱の圧縮強度——

$$
\begin{array}{llll}
\text { 正員 } & \text { 藤 } & \text { 田 } & \text { 譲* } \\
\text { 正員 } & \text { 高員 吉田宏一 郎* }
\end{array}
$$

On the Strength of Structures with Imperfections (1st Report)

Compressive Strength of Columns with Initial Imperfections-

by Yuzuru Fujita, Member Koichiro Yoshida, Member

Makoto Takazawa, Member

Summary

Structural elements of actual structures usually have several kinds of imperfections ; initial deflections, residual stresses, unexpected discontinuities of structural components and so on. These imperfections may severely weaken the strength of structures designed based on the ideal states of structures.

It is necessary to clarify the effects of imperfections not only qualitatively but also quantitatively. The theoretical analysis of the structures with imperfections, however, will not so easy in many cases partly because linear problems will become non-linear ones and in some cases two dimensional problems will become three dimensional ones and partly because it will be difficult to consider a suitable analytical models for so small amount of imperfections.

In this paper, the effects of initial deflections of columns on the compressive maximum loads are investigated where columns are assumed to be under the combined states of axial compression and one-dimensional bending.

The compression tests of 20 rectangular section columns and $8 \mathrm{H}$-type section columns with sine half wave type initial deflections were conducted.

The analytical solutions were computed by using incremental Finite Element technique. The accordance of both results was satisfactory.

Moreover, the maximum compressive loads of columns with irregular type initial deflections or with rotationally restrained ends were obtained theoretically.

\section{1 は じめに}

実際の構造物中に存在する構造要素は, 各種の原因により不整量を有しているのが通例であり, 初期撓み, 残 留応力等の初期応力, あるいは構造不連続等はこの例である。これらの不整量が理想状態として設計された構造 物の強度を想像以上に低下せしめ, 予想外の状態で構造物の崩壊が生ずることが考えられるので, その定性的把 握は勿論, 定量的把握が十分にされることが必要である。しかしながら，これらの不整量を考慮して，構造物の 挙動を解析することは，理想状態では，線型の取扱いで済むものが，非線型になったり，2次元の取扱いが， 3 次元になったり，あるいは，極く微小量を取扱うことになるのでモデル化がむずかしくなるという様な各種の困 難が生じてくることが多い。

ここでは, 最も基本的な問題の 1 つである, 一方向のみに曲りらる柱が, 軸圧縮力を受ける場合の最高荷重に

\footnotetext{
* 東京大学工学部船舶工学科
} 


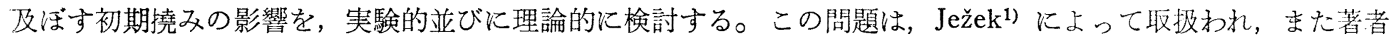
等によっても，柱の二軸曲げ問題 ${ }^{2)}$ ，および一般的な Beam-Column 問題3)の一環としてい及されている。しふ しながら，初期撓みの形状・大きさ等が，柱の圧縮強度に及ぼす影響に関する系統的研究执よび実験による裏付 けが不十分なため，これを明らかにして，設計の一資料を提出することを試みた。

\section{2 初期撓みを有する柱の圧縮実験と数値計算}

\section{1 矩型断面柱およびH型断面柱の圧縮実験}

矩形括よびH型断面の柱の断面寸法をそれぞれ一定として，その細長比を矩形断面柱では，40,60, 80, 100, 120 の 5 種類， H型断面柱では，40，60 の 2 種類に変化させ，その各々の細長比については，注注 sine の半波長の 形状の初期撓み（以後，規則的な初期撓みと称する）の大ささを，4段階に变化させた，部 28 本の試験片を， 主にその最高荷重に注目して，両端回転拘束なしの条件で，両断面とも弱軸まわりの曲げになる様に圧縮した。

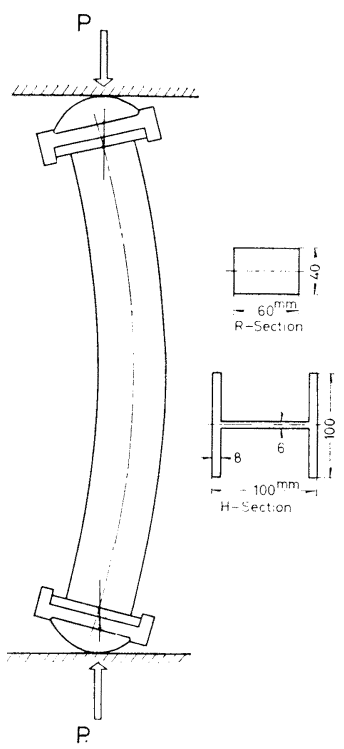

Fig. 1 Compressiom Test Arrangement 試験片の装着状況执よび用いた 2 種類の断面の公称寸法を Fig. 1 に 示す。両端回転拘束なしの条件は, 試験片の雨端部にカマボコ型の 端部装置によって得る様にした。初期撓みは, 真直な柱に 4 点曲げ 荷重を加え，それを応力焼鈍してつけた。Fig. 2 に初期暁みの測定 值の例を示す。

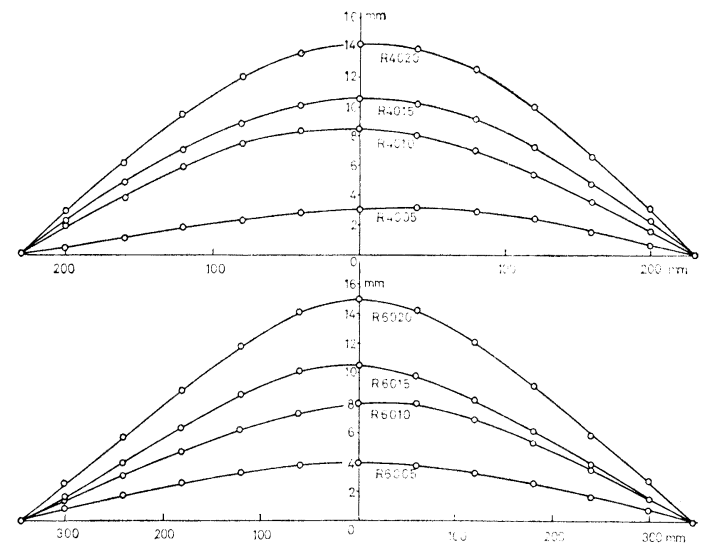

Fig. 2 Initial Deformation

\section{2 計 算 法}

両端での境界条件，初期撓みの形状が比較的任意に取扱い得る利点を有する有限要素法による計算を行った。 柱をその軸にとって相当数の梁要素に分割し, 個々の梁要素については, 梁理論を適用して要素の剛性行列を導 く。この場合, 軸方向の歪の算定に横撓みの影響を考える有限変位理論を用いる。この様な幾何学的非線型性に 加え, 最高荷重附近に和ける歪の大きい状態までを考慮するために必然的に梁断面の一部が塑性域になる材料非 線型性も入ってくる。この 2 種類の非線型性は, 共に部分的な線型化を仮定する荷重增分法によって解かれるが， 線型化の仮定のために入ってくる䛊差については，前段階の不平衡力によって外力增分を修正するといら方法で 補正を行った。以下に有限要素法による表現の基礎式を，一般の 3 次元の有限変位増分理論 ${ }^{4}$ 上り導く。

ある状態から，それに隣接する新しい状態に移る場合，仮想仕事の原理により

$$
\begin{aligned}
& \frac{1}{2} \iiint_{V} \delta\left(\Delta \sigma_{\lambda \mu} \Delta \varepsilon_{\lambda \mu}\right) d V+\frac{1}{2} \iiint_{V} \sigma_{\lambda \mu} \delta\left(\Delta u_{K, \lambda} \Delta u_{K, \mu}\right) d V-\iiint_{V} \Delta \bar{X}_{\lambda} \delta \Delta u_{\lambda} d V \\
& \quad-\iint_{S_{1}} \Delta \bar{P}_{\lambda} \delta \Delta u_{\lambda} d S+\left(\iiint_{V} \sigma_{\lambda \mu} \delta \Delta \varepsilon_{\lambda \mu} d V-\iiint_{V} \bar{X}_{\lambda} \delta \Delta u_{\lambda} d V-\iint_{S_{1}} \bar{P}_{\lambda} \delta \Delta u_{\lambda} d S\right)=0
\end{aligned}
$$

$\Delta$ は増分量を表わし， $\bar{X}$ は物体力， $\bar{P}$ は力学境界 $S_{1}$ に扬壮る境界力である。 $\Delta \varepsilon_{\lambda \mu}$ は，変位増分の線型項によ る歪増分である。旧状態に拈ける外力，内力执よびそれらの増分量も， $\delta \Delta u_{\lambda}$ に関して不变として，

$$
\delta(\Delta \pi)=0
$$


ここで

$$
\begin{aligned}
\Delta \pi= & \frac{1}{2} \iiint_{V} \Delta \sigma_{\lambda \mu} \Delta \varepsilon_{\lambda^{\mu}} d V+\frac{1}{2} \iiint \sigma_{\lambda^{\mu}}\left(\Delta u_{K, \lambda} \Delta u_{K, \mu}\right) d V-\iiint_{V} \Delta \bar{X}_{\lambda} \Delta u_{\lambda} d V \\
& -\iint_{S_{1}} \Delta \bar{P}_{\lambda} \Delta u_{\lambda} d S+\left(\iiint_{V} \sigma_{\lambda \mu} \Delta \varepsilon_{\lambda \mu} d V-\iiint_{V} \bar{X}_{\lambda} \Delta u_{\lambda} d V-\iint_{S_{1}} \bar{P}_{\lambda} \Delta u_{\lambda} d S\right)
\end{aligned}
$$

有限要素法による $\Delta \pi$ は，要素に関する $\Delta \pi_{E}$ の和である。 $\Delta \pi_{E}$ は，要素に関する局部座標系で考える。

(3) 上り

$$
\begin{gathered}
\Delta \pi_{E}=\frac{1}{2} \Delta \boldsymbol{\delta}^{T}\left(\iiint_{V_{E}} \boldsymbol{B}^{T} \boldsymbol{D} \boldsymbol{B} d V\right) \Delta \boldsymbol{\delta}+\frac{1}{2} \Delta \boldsymbol{\delta}^{T}\left(\iiint_{V_{E}} \sigma_{\lambda \mu} \boldsymbol{G}_{,{ }_{\lambda}} \boldsymbol{G}_{, \mu} d V\right) \boldsymbol{\Delta \boldsymbol { \delta }} \\
-\Delta \boldsymbol{Q}^{T} \Delta \boldsymbol{\delta}+\left(\iiint_{V_{E}} \boldsymbol{\sigma}^{T} \boldsymbol{B} d V\right) \Delta \boldsymbol{\delta}-\boldsymbol{Q}^{T} \Delta \boldsymbol{\delta}
\end{gathered}
$$

ここで

$$
\begin{gathered}
\Delta \boldsymbol{\sigma}=\boldsymbol{D} \Delta \boldsymbol{\varepsilon}, \quad \Delta \boldsymbol{\varepsilon}=\boldsymbol{B} \Delta \boldsymbol{\delta}, \quad \Delta \boldsymbol{u}=\boldsymbol{G} \Delta \boldsymbol{\delta}, \quad \Delta \boldsymbol{Q}=\iiint_{V_{E}} \boldsymbol{G}^{T} \Delta \overline{\boldsymbol{X}} d V+\iint_{S_{1 E}} \boldsymbol{G}^{T} \Delta \overline{\boldsymbol{P}} d S \\
\Delta \boldsymbol{\delta} \text { は，節点変位增分ベクトル }
\end{gathered}
$$

局所座標系から全体座標系への座標変換，足し込々を行い， $\Delta \pi$ を求める。

$$
\Delta \pi=\frac{1}{2} \Delta \boldsymbol{\delta}_{S}{ }^{T} \boldsymbol{K} \Delta \boldsymbol{\delta}_{S}+\frac{1}{2} \Delta \boldsymbol{\delta}_{S}{ }^{T} \boldsymbol{K}_{G} \Delta \boldsymbol{\delta}_{S}-\Delta \boldsymbol{Q}_{S}{ }^{T} \Delta \boldsymbol{\delta}_{S}+\left(\boldsymbol{R}^{T} \Delta \boldsymbol{\delta}_{S}-Q_{S}{ }^{T} \Delta \boldsymbol{\delta}_{S}\right)
$$

ここで

$$
\begin{aligned}
\boldsymbol{K} & =\Sigma \boldsymbol{T}_{E}{ }^{T}\left(\iiint_{V_{E}} \boldsymbol{B}^{T} \boldsymbol{D} \boldsymbol{B} d V\right) \boldsymbol{T}_{E}, \quad \boldsymbol{K}_{G}=\Sigma \boldsymbol{T}_{E}{ }^{T}\left(\iiint_{V_{E}} \sigma_{\lambda \mu} \boldsymbol{G}^{T}{ }_{, \lambda} \boldsymbol{G}_{, \mu} d V\right) \boldsymbol{T}_{E} \\
\boldsymbol{R} & =\Sigma \boldsymbol{T}_{E}\left(\iiint_{V_{E}} \boldsymbol{B}^{T} \boldsymbol{\sigma} d V\right) \\
& \boldsymbol{T}_{E} \text { は座標変換行列, } \Delta \boldsymbol{\delta}_{S} \text { は全体座標系での節点変位增分ベクトル }
\end{aligned}
$$

停留原理により，

$$
\left(\boldsymbol{K}+\boldsymbol{K}_{G}\right) \Delta \boldsymbol{\delta}_{S}=\Delta \boldsymbol{Q}_{S}-\left(\boldsymbol{R}-\boldsymbol{Q}_{S}\right)
$$

右辺の第 2 項は, 旧状態に执いて内力と外力との平衡が不完全なために生ずる項で, この項を不平衡力と考兄 て, 上式に従って外力增分の補正項として考慮する。

ここでは, 柱の一軸曲げ問題であるので, 上式は応力, 歪の一次元となる。変位については, 軸方向は 1 次,

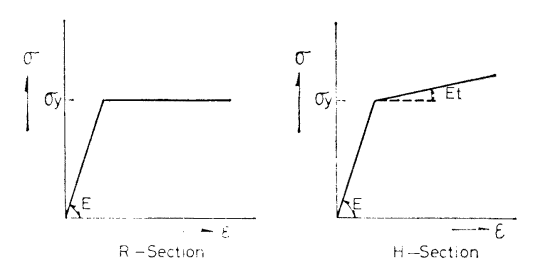

Fig. 3 Assumed Stress Strain Diagrams

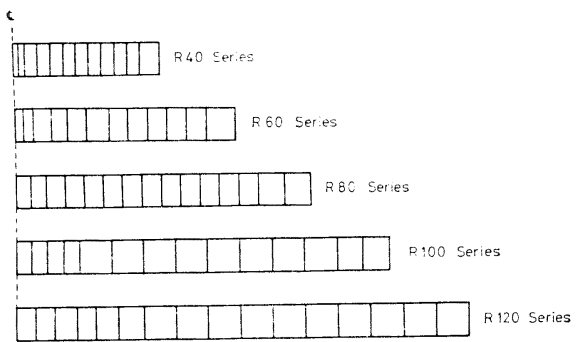

Fig. 4 Element Subdivisions of R-Sections

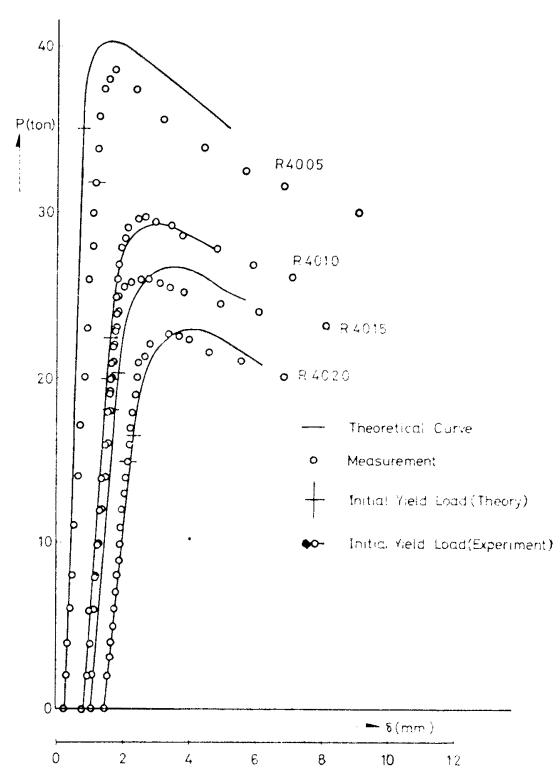

Fig. 5 Load-Central Deflection Curves (R 40 Series) 


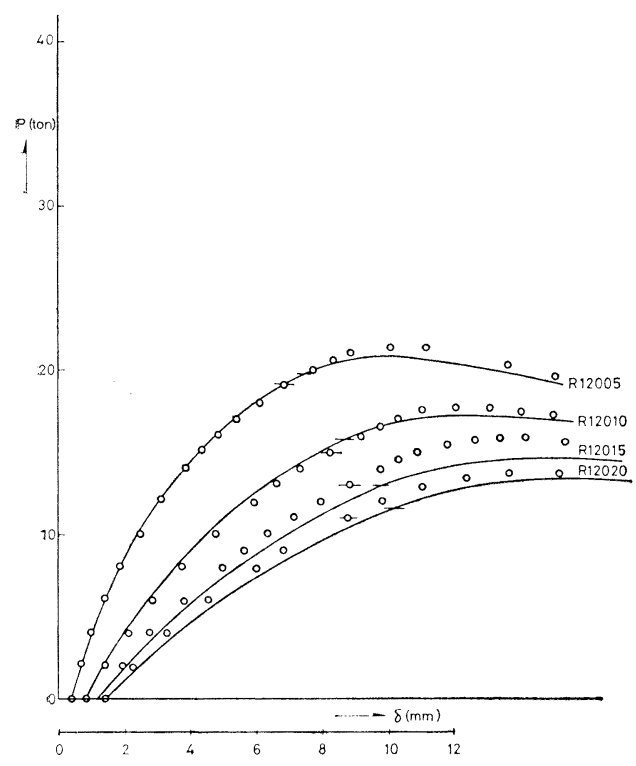

Fig. 6 Load-Central Deflection Curves (R!120 Series)

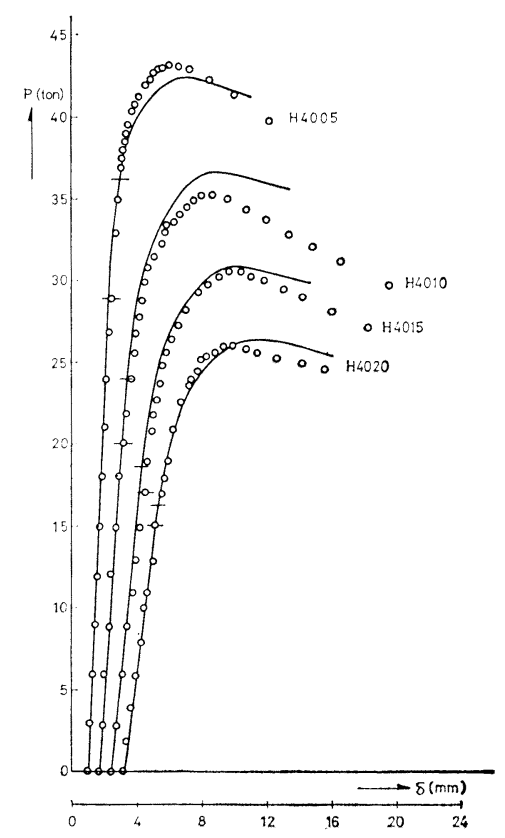

Fig. 7 Load-Central Deflection Curves (H 40 Series)

Table 1 Experimental and Calculated Results

\begin{tabular}{|c|c|c|c|c|c|c|c|c|c|}
\hline \multirow{2}{*}{ Specimen } & \multirow{2}{*}{$\begin{array}{c}\text { Slenderness } \\
\text { Ratio } \\
1 / r\end{array}$} & \multicolumn{2}{|c|}{$\begin{array}{l}\text { Initial Deflection } \\
\text { Ratio }\end{array}$} & \multicolumn{2}{|c|}{$\begin{array}{l}\text { Experimental } \\
\text { Maximum Load }\end{array}$} & \multicolumn{2}{|c|}{$\begin{array}{l}\text { Theoretical } \\
\text { Maximum Load }\end{array}$} & \multirow{2}{*}{\begin{tabular}{|l|}
$\begin{array}{l}\text { Error } \% \\
(P \text { max }) t-\left(P_{\text {max }}\right)^{x}\end{array} 100$ \\
$(P$ max $) e$ \\
\end{tabular}} & \multirow{7}{*}{$\begin{array}{c}\sigma_{y}=21.5 \mathrm{~kg} / \mathrm{mm}^{2} \\
\text { for } R-\text { Section } \\
=28.6 \mathrm{~kg} / \mathrm{mm}^{2} \\
\text { for } H-\text { Section }\end{array}$} \\
\hline & & $a / r$ & $\mathrm{a} / 1$ & (Pmax)e & $\left(\mathrm{P}_{\max }\right) / \mathrm{Py}$ & $\left(P_{\max }\right) t$ & $\left(P_{\max }\right) t / P_{y}$ & & \\
\hline$R 4005$ & \multirow{4}{*}{40} & 0.262 & 0.00655 & 38.6 & 0.757 & 40.3 & 0.791 & 4.3 & \\
\hline$R 4010$ & & 0.742 & 0.0186 & 29.8 & 0.585 & 29.4 & 0.577 & -1.2 & \\
\hline$R 4015$ & & 0.912 & 0.0228 & 25.9 & 0.510 & 27.0 & 0.531 & 4.2 & \\
\hline$R 4020$ & & 1.232 & 0.0308 & 22.6 & 0.444 & 23.2 & 0.456 & 2.5 & \\
\hline$R 6005$ & \multirow{4}{*}{60} & 0.341 & 0.00568 & 33.7 & 0.664 & 34.6 & 0.682 & 3.0 & \\
\hline$R 6010$ & & 0.707 & 0.0118 & 24.5 & 0.482 & 27.2 & 0.535 & 11.2 & \multirow{7}{*}{$\begin{array}{l}E=2.1 \times 10^{4} \mathrm{~kg} / \mathrm{mm}^{2} \\
\text { for both Section } \\
E t=0 \mathrm{~kg} / \mathrm{mm}^{2} \\
\text { for } R-S e c t i o n \\
=2.1 \times 10^{2} \mathrm{~kg} / \mathrm{mm}^{2} \\
\text { for } \mathrm{H}-\text { Section }\end{array}$} \\
\hline$R 6015$ & & 0.931 & 0.0155 & 23.8 & 0.470 & 24.5 & 0.484 & 2.2 & \\
\hline $\mathrm{R} 6020$ & & 1.311 & 0.0218 & 19.8 & 0.391 & 20.4 & 0.403 & 2.9 & \\
\hline $\mathrm{R} 8005$ & \multirow{4}{*}{80} & 0.368 & 0.00460 & 32.9 & 0.648 & 29.6 & 0.583 & -10.2 & \\
\hline$R 8010$ & & 0.592 & 0.00740 & 28.9 & 0.570 & 25.9 & 0.511 & -10.4 & \\
\hline$R 8015$ & & 0.993 & 0.0122 & 20.9 & 0.412 & 20.4 & 0.402 & -2.5 & \\
\hline$R 8020$ & & 1.332 & 0.0167 & 19.8 & 0.391 & 17.7 & 0.350 & -10.7 & \\
\hline$R 10005$ & \multirow{4}{*}{100} & 0.299 & 0.00299 & 31.2 & 0.617 & 26.5 & 0.524 & -15.2 & \multirow{16}{*}{$\begin{array}{l}1: \text { length } \\
r: \text { radius of } \\
\text { gyration } \\
a: \text { initial } \\
\text { deflection at } \\
\text { midpoint }\end{array}$} \\
\hline$R 10010$ & & 0.646 & 0.00646 & 21.3 & 0.421 & 20.7 & 0.409 & -2.9 & \\
\hline$R 10015$ & & 1.027 & 0.0103 & 17.6 & 0.348 & 17.2 & 0.340 & -2.3 & \\
\hline $\mathrm{R} 10020$ & & 1.318 & 0.0132 & 15.7 & 0.310 & 15.3 & 0.303 & -2.6 & \\
\hline$R 12005$ & \multirow{4}{*}{120} & 0.365 & 0.00304 & 21.5 & 0.425 & 20.8 & 0.411 & -3.1 & \\
\hline$R 12010$ & & 0.711 & 0.00593 & 17.8 & 0.352 & 17.2 & 0.341 & -2.6 & \\
\hline $\mathrm{R} 12015$ & & 1.058 & 0.00882 & 15.9 & 0.312 & 14.7 & 0.289 & -7.5 & \\
\hline $\mathrm{R} 12020$ & & 1.283 & 0.0107 & 13.8 & 0.273 & 13.4 & 0.266 & -2.6 & \\
\hline $\mathrm{H} 4005$ & \multirow{4}{*}{40} & 0.410 & 0.0103 & 43.1 & 0.739 & 42.6 & 0.731 & -1.1 & \\
\hline $\mathrm{H} 4010$ & & 0.679 & 0.0170 & 35.4 & 0.599 & 36.9 & 0.624 & 4.2 & \\
\hline H4015 & & 0.962 & 0.0241 & 30.7 & 0.525 & 31.1 & 0.531 & 1.2 & \\
\hline $\mathrm{H} 4020$ & & 1.283 & 0.0321 & 26.1 & 0.440 & 26.5 & 0.446 & 1.5 & \\
\hline $\mathrm{H} 6005$ & \multirow{4}{*}{60} & 0.400 & 0.00667 & 36.3 & 0.620 & 36.5 & 0.624 & 0.7 & \\
\hline $\mathrm{H} 6010$ & & 0.669 & 0.0112 & 30.5 & 0.502 & 31.6 & 0.520 & 3.5 & \\
\hline H6015 & & 0.939 & 0.0157 & 25.1 & 0.418 & 26.6 & 0.443 & 5.9 & \\
\hline H6020 & & 1.291 & 0.0215 & 21.8 & 0.373 & 22.1 & 0.378 & 1.3 & \\
\hline
\end{tabular}


撓みは 3 次の変位関数を用い, 材料の応力-歪関係は，それぞれの材料試験結果を参考として，矩形断面柱につ いては完全弾塑性体，H型断面柱については歪硬化材 $\left(E_{t}=(1 / 100) E\right)$ と仮定した (Fig. 3)。

圧縮試験片は，長さの中央に関して対称と仮定して計算したが，その要素分割例をFig.4 と示す。

\section{3 実験值と計算值との比較}

圧縮荷重と中央点の撓みとの関係の例を Fig. 5 Fig.7 に示す。ここで，撓みは各試験片の荷重の 0 点を原 点として，横軸の下に描かれているスケールによる附加撓みである。細長比，初期撓みがともに小さい場合に は，軸圧縮成分が大きいため，圧縮力と附加撓及との関係は，注ぼ直線でしかも勾配が大きく，最高荷重後は急 激に減少する（R 4005）。一方，細長比，初期撓みがともに大きい場合には，曲げ成分の効果が相対的に大きく なり，圧縮力と附加撓みとの関係は，直線からはずれ，勾配も小さく，最高荷重後も荷重の減少が小さい（R 12020)。

全試験片について，実験による最高荷重，計算による最高荷重，誤差を表にしたものが Table 1 である。ま た, 細長比 $l / r$ を助変数として, 横軸に初期撓み, 綎軸に最高荷重を示したのが, Fig. 8 およよび Fig. 9 である。計 算值の内，実際の圧縮試験片の存在するものは，測定された初期撓みを用い，対応する試験片のないるのには規 則的な初期撓及形状を仮定し, 断面寸法, 材料定数には圧縮試験片の公称值を用いた。そのため, 細長比を一定 としても，敛密には一本の曲線として表示できない場合もあるわけであるが，圧縮試験片の初期撓み形状は，す べてにわたってほぼ sine 半波形に近いので, 一応, 一本の曲線で結しである。結果として, ほとんぞの場合, なめらかに結ばれている。

これらの図で, 各曲線の縦軸との交点は, 矩形断面柱については, 応力-歪曲線を Fig. 3 の様に仮定している ので, 弾性域では Euler 曲線, 塑性域では $\sigma_{Y} に 入 れ ， H$ 型断面柱では歪硬化を考兄ているので, 弾性域では, やはり Euler 曲線，塑性域では，曲線の右側からのなめらかな延長点としている。

\section{3 規則的な初期撓みを有する柱の Column Curves}

Fig. 8 と Fig. 9 の曲線を基として, $a / r$ を助变数とし, 横軸に材料定数を考慮した細長比 $l / r \sqrt{\sigma_{Y} / E}$ をとり, 縦軸化最高荷重時の平均応力の無次元量 $\sigma_{\mathrm{max}} / \sigma_{Y}$ をとって描いた Column Curves が, Fig. 10 (矩形断面), Fig.11 (H型断面)である。また助変数に a/l をとり，Ježek の計算と比較したものが Fig. 12 である。図中の 破線で示される Ježek の結果は，初期撓みの形状を中央点に関して対称な放物線を仮定したものであり，実線

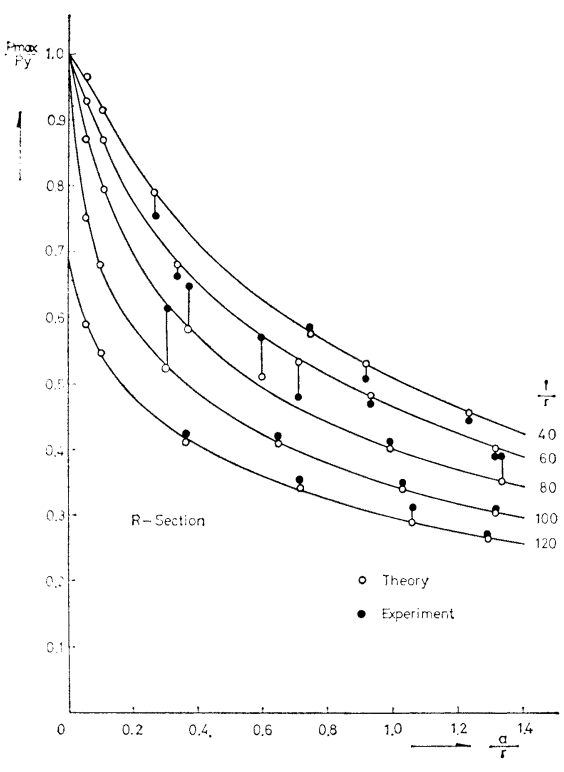

Fig. 8 Relation between Maximum Loads and Initial Deformations of Rectangular Sections

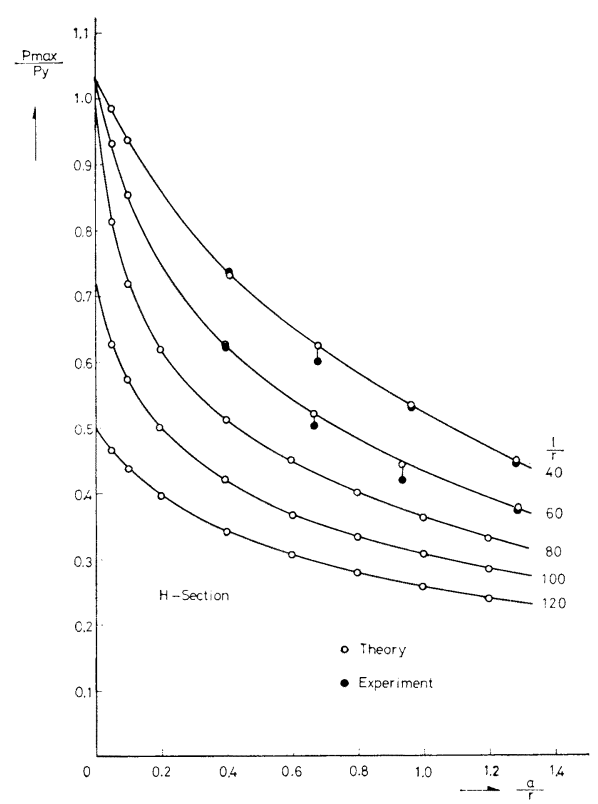

Fig.9 Relation between Maximum Loads and Initial Deformations of H-Sections 


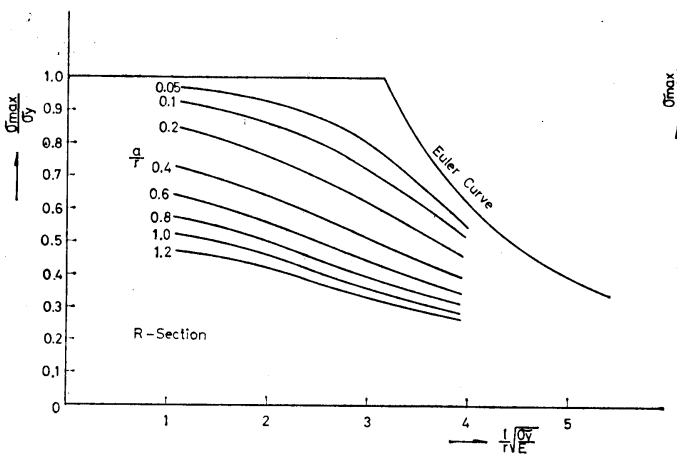

Fig.10 Column Curves of Rectangular Sections

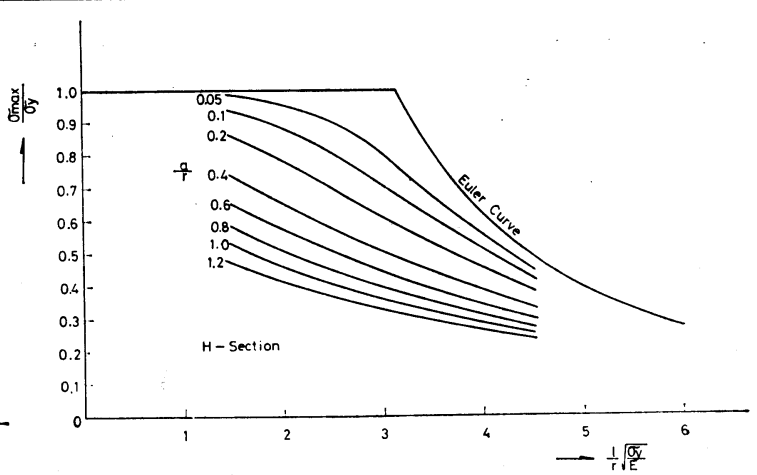

Fig. 11 Column Curves of H-Sections

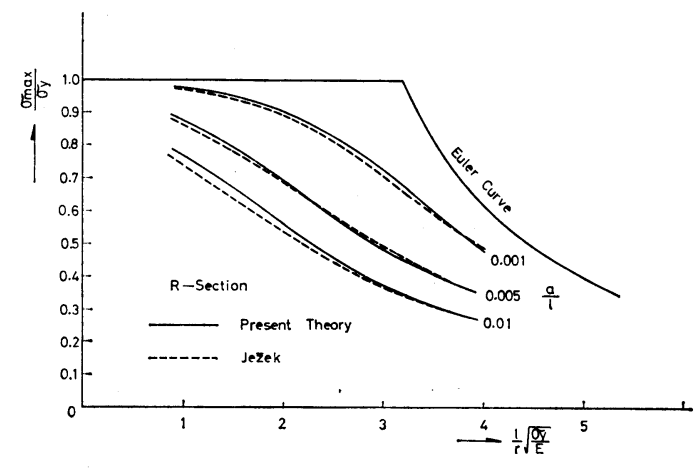

Fig.12 Comparison of Present Theory with Ježek

Table 2 Calculated Results for Various Initial Deformations

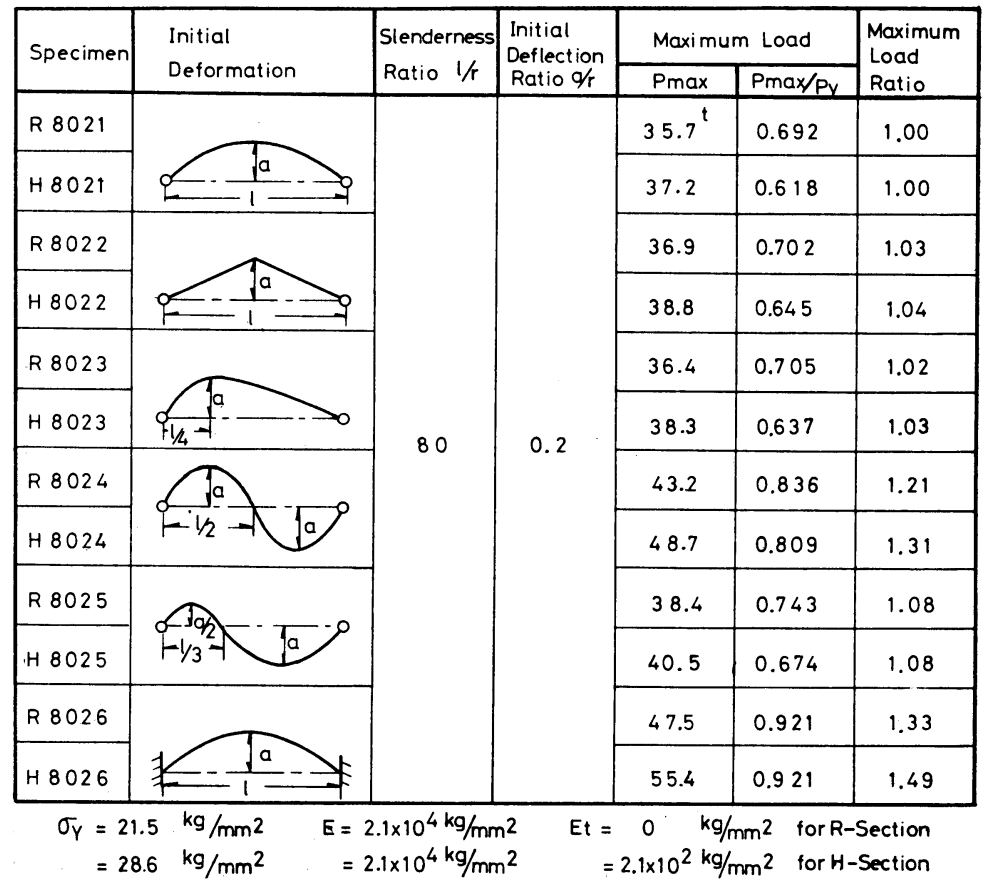


は sine 半波形を仮定したものであるが, Ježek の放物線は, 数值的に sine 半波形に非常に近いものであるた め郎い一致を示している。

\section{4 不規則な初期撓みを有する柱の圧縮強度}

これまで取扱ってきた柱は，初期撓みが規則的で，かつ両端で回転拘束がないものであった。この様な状態 が，最も柱の王縮独度を弱めるものであるうことは推察されるわけであるが，他の初期撓みの形状，あるいは境 界条件の場合には，最高荷重はどらなるであろうか。有限要素法を用いた本諭文の解析法の場合，これらの検討 が寒绍に行いらる。4 種類の sine 半波形以外の場合と，両端を回転拘束した場合の計算結果を表にしたものが Table 2 である。1 種類の初期撓み形状に対して, 矩形断面（R 試験片）と $\mathrm{H}$ 型断面（H試験片）の 2 種類を取 扱った。断面方法扣よび材料定数は，王縮試験に用いた試験片の公称值と同一である。 8021 試験片は，規則的 形状の場合で，不規則な形状の場合の基準とするるのである。 8022 試験片は，中央点に関して詨称であるが直 線的に変化しているもの，8023 試験片は，l/4 の所に最大撓みがあるものである。 8024 試験片は, 完全な sine 1 淡の形状を有するもの， 8025 試験片は， $l / 3$ の所に最大撓みがある不完全 1 波のもの, 8026 試験片は, 規則 的な初期挬又を有する柱の雨端を回転拘束とした場合である。

Table 2 の最右闌に，8021 試験片を基準とした場合の上昇率が示されている。 8022 試験片，8023 試験片に ついては，その上昇率は極くわずかであるが， 8024 試験片については，かなりの強度上昇がある。この試験片 の場悀，計筧結果によれば，荷重の増加にともなら撓みの増加は，初期撓みの形状がそのまま保持され，中央点 は変位せず, 考えている柱の半分の長さの柱で, 雨端回転拘束なしの場合と全く同一であり, 最高荷重もFig. 8, Fig. 9 で $l / r=40$ として読みとれる值と数值䛊差の範囲内で一致している。実際に，この様な形状の柱を圧縮し た場合には，途中の荷重で，半波のモードに飛び移ることが十分考えられる。しかし，本解析の場合には，平衡 状態を，次々に追跡する計算法であり，安定・不安定の判定の考えが入っていないため，計算上，上述の様にな ったものと考えられる。

R 8025 陚験片について，撓み形状が次第に変化してゆく様子を，Fig.13 に示す。羽中，黒く塗りつぶした領 域は，その侕重段階での塑性域の広がりを示している。Fig. 14 には, R 8026 試験片についての同様の図を示す。

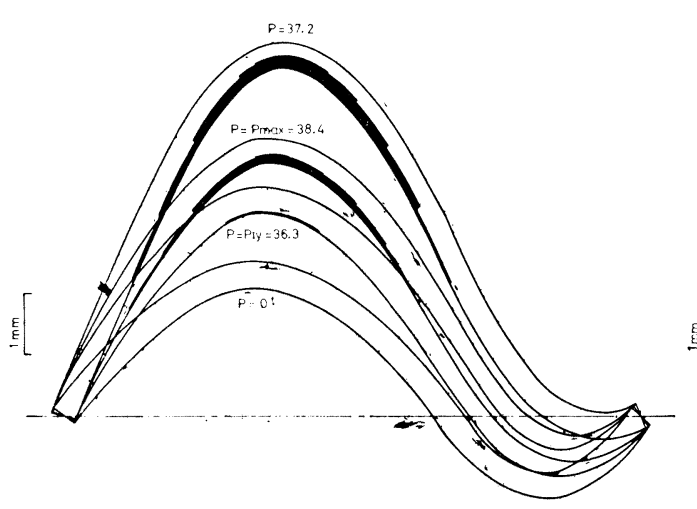

Fig. 13 Deformations of R 8025 Specimen

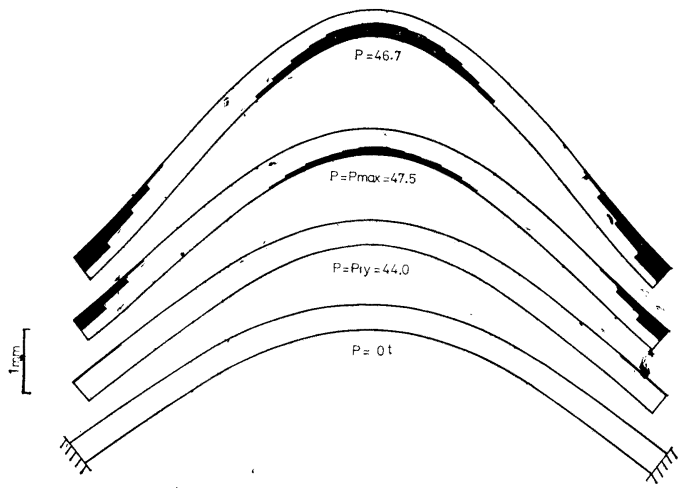

Fig. 14 Deformations of R 8026 Specimen

\section{5 ま と め}

（1） sine 半波形に近い初期撓みを有する，矩形断面柱拉よびH型断面柱を，両端回転拘束なしの条件で圧 縮笑験を行い, 有限要素法による解と比較した結果, 荷重一撓み曲線, 最高荷重ともほぼ良い一致を示した。

（2）矩形断面柱扣よび H型断面柱に関して， sine 半波形の初期撓みを有し，両端回転拘束なしの場合の Column Curves を計算した。矩形断面の場合の Curves は，Ježek の結果とほぼ一致した。

（3） sine 半波形以外の各種初期撓みを有する場合，および両端回転拘束の場合について最高荷重を計算し た。 
謝 辞

本論文の終りにあたり，内容をご検討戴いた日本大学倉西正䐀教授を始めとする日本鋼構造協会座屈研究委員 会, 及び日本溶接協会塑性設計研究委員会の委員の方々に拉礼申上げます。また, 当時東大船舶工学科学生とし て, 本研究の一部を卒業論文として行った小野塚正一, 藤原幸男 ${ }^{5}$, 川野始, 小崎文雄 ${ }^{6}$ の各氏, 特よび実験・図 面作成にご助力戴いた金子幸平氏を始めとする東大船舶工学科強弱実験室の方々のご協力に感謝致します。

参 考文 献

1) Ježek, K. : Die Festigkeit von Druckstäben aus Stahl, Julius Springer, (1937).

2) 藤田 譲, 吉田宏一郎, 大勝孝司：二軸曲げを受ける柱の弾塑性解析（その 2), 日本造船学会論文集第 127 号 (1970).

3）藤田 譲, 大坪英臣, 湯原哲夫：構造物の塑性設計（その11）, 日本造船学会論文集第 129 号 (1971).

4) Washizu, K. : Variational Methods in Elasticity and Plasticity, Pergamon Press, (1966).

5）小野塚正一，藤原幸男：柱の圧縮に拈ける Initial Imperfection の影響, 東京大学船舶工学科卒業論文, (1971).

6) 川野 始, 小崎文雄：初期撓みを有する柱の弾塑性曲げ強度について, 東京大学船舶工学科卒業論文, (1972). 